\title{
Report confirms obstacles to women scientists
}

London. Evidence of the British government's poor record in promoting women scientists to senior positions is expected to be revealed in a report on women in science to be published today ( 24 February) by the Office of Science and Technology (OST).

The report is expected to confirm concern raised in the government's white paper (policy document) Realising our Potential that women are "the country's biggest single most under-valued and under-used human resource". It shows that this is true not merely in scientific research, but also in the membership of public committees and advisory boards in fields related to science and engineering.

OST's two major committees, for example, the Council for Science and Technology (CST) and the Technology Foresight Steering Group, are made up of 21 men and just one woman, Bridget Ogilvie, director of the Wellcome Trust. The research councils emerge only slightly better. The four natural science research councils are made up of 76 men, and only six women (see table above).

The councils are being reorganized on 1 April, but so far no women have been named in key positions. Indeed, although these poor figures are in part inherited by William Waldegrave, the science minister, from his predecessors, there seems little evidence of any improvement over the past 12 months.

According to a parliamentary reply given by Waldegrave earlier this month, for six of the top jobs filled by open competition during this period, there were 21 female applicants out of a total of 317 , and none was successful. For ten research council posts, there were only two female applicants, and again neither was successful.

Last December, Helen Williams was appointed head of the transdepartmental science and technology group in the OST, a grade 3 post. She ended a run of 12 months up to the end of September 1993 when no females were appointed to any of the 24 senior OST posts at the grade 3 , 4 or 5 levels which were filled internally.

"It is simply a case of going for the best person irrespective of gender," says Doreen Melville-Riddell a spokeswoman for the Office of Public Service and Science. She says that the Civil Service has a good record on equal opportunities, but that it is "not something you can change overnight by snapping your fingers".

But Michael Meacher, the Labour Party's spokesman on public services and science, who brought the government's recent record to light, says it is "incredible" that none of the women who applied for the vacant positions were considered appropriate for the job. "The government should be

\section{Coming to a screen near you...}

London. In a move that marks the first step of a project to make the British Library's collection of historical manuscripts available to researchers across the world, images - such as that opposite - from an eleventh century manuscript of the poem Beowulf have been published electronically.

Lettering covered by paper mounts used to protect the document after it was damaged by fire in 1731 shows up because researchers used fibre-optic cable to backlight the document. Pages have been photographed in colour for the first time, and the ultraviolet light shows up erased corrections and microscopic detail in the parchment itself.

Selected folios from the manuscript are available on the Internet. The image files had to be compressed, as the originals are about 22 megabytes in size; as a result, they do not show the same high resolution. The entire manuscript will eventually be available in a variety of formats, including CD-ROM and network access, and visitors to the library will be able to call up the images on terminals.

"It is not yet possible to put everything

\section{IMAGE UNAVAILABLE FOR COPYRIGHT REASONS}

out because the images are very large," says Andrew Prescott, curator of western manuscripts at the library. "But it does mark the first step." taking a lead here," says Meacher. "I hope the OST report has some pointers, because William Waldegrave obviously needs them."

Bill Stewart, the chief scientific adviser to the government, has said in an interview published in the Association of University Teachers' Bulletin that the report looks at three broad areas; education - girls' interointments to sclencerelated boards

\begin{tabular}{|lccl|}
\hline & Men & Women & Dept \\
\hline Council for Science and Technology & 11 & 1 & OST \\
Technology Foresight Steering Group & 10 & 0 & OST \\
Agricultural and Food Research Council & 21 & 1 & OPSS \\
Medical Research Council & 18 & 2 & OPSS \\
Natural Environment Research Council & 19 & 1 & OPSS \\
Science and Engineering Research Council & 17 & 2 & OPSS \\
\hline
\end{tabular}

ST, Office of Science and Technolog

Public Services and Science

est in science and technology subjects; employment - reconciling a scientific career with family responsibilities and career breaks; and, women at the top - the number of women in senior positions and public appointments. The report is expected to be the most comprehensive study of the current situation for women pursuing scientific careers.

The report, which was originally expected last autumn, is thought to have been delayed by the reshuffling of the research councils. Nancy Lane, who is a member of the Women in Science and Technology Committee and also chairs the working group that compiled the report for the committee, says that "the white paper had to take prominence, and 'women in science' fell into second place".

The Royal Society has already set up its own separate study on the obstacles faced by women scientists. "The society's officers agree with the concern raised in the white paper, and have been examining the society's activities to identify ways of promoting and supporting women scientists," says John Horlock, the treasurer and vice president of the society.

One conclusion reached by the working group in a study of women scientists working in other countries was that networking is important. Although there are active groups in certain disciplines, such as the Women's Engineering Society, the Women in Physics Committee of the Institute of Physics and the Women Chemists' Committee of the Royal Society of Chemistry, there is no nationwide group of women in science. In particular, women in biology and biomedical science have no such group.

Joan Mason, the secretary of the working group, says that officials at the OST felt such an organization should be a 'grassroots' movement. She has therefore arranged for the launch on 25 March in Cambridge of an umbrella organization, the Association for Women in Science and Engineering in the UK (AWISE).

Flona Gammie 